Abstracta Iranica

Revue bibliographique pour le domaine irano-aryen

Volume 34-35-36 | 2017

Comptes rendus des publications de 2011-2013

\title{
Parsa Ghasemi. Tal-e Khandagh (" Moated Mound )). A Military Structure in Ancient Fars
}

\section{Rémy Boucharlat}

\section{(2) OpenEdition}

1 Journals

\section{Édition électronique}

URL : http://journals.openedition.org/abstractairanica/41796

DOI : 10.4000/abstractairanica.41796

ISSN : 1961-960X

Éditeur :

CNRS (UMR 7528 Mondes iraniens et indiens), Éditions de l'IFRI

Référence électronique

Rémy Boucharlat, "Parsa Ghasemi. Tal-e Khandagh (" Moated Mound "). A Military Structure in Ancient Fars », Abstracta Iranica [En ligne], Volume 34-35-36 | 2017, document 14, mis en ligne le 30 décembre 2016, consulté le 26 septembre 2020. URL : http://journals.openedition.org/abstractairanica/41796 ; DOI : https://doi.org/10.4000/abstractairanica.41796

Ce document a été généré automatiquement le 26 septembre 2020.

Tous droits réservés 


\title{
Parsa Ghasemi. Tal-e Khandagh (" Moated Mound »). A Military Structure in Ancient Fars
}

\author{
Rémy Boucharlat
}

\section{RÉFÉRENCE}

Parsa Ghasemi. « Tal-e Khandagh (« Moated Mound )). A Military Structure in Ancient Fars ». Near Eastern Archaeology, 75/4, 2012, p. 240-251.

1 Ce nom générique (colline [entouré par un] fossé en général circulaire est donné à une série de sites archéologiques dans le Fars méridional et occidental. Un temps interprété comme un daḦme (Tour du Silence) pour celui de Sarmašhad par L. Trümpelman, ce type de relief représente en fait un établissement fortifié de 80 à $150 \mathrm{~m}$ de diamètre, entouré d'un fossé qui peut atteindre $30 \mathrm{~m}$ de largeur. Quelques sondages ont révélé un rempart en terre ou en briques crues. Le matériel trouvé alors dans ceux-ci et lors des prospections de surface permet de les dater de l'époque sassanide. L'A. propose de reconnaître dans ces constructions le siège de petites garnisons installées par le pouvoir royal pour assurer la sécurité locale. S'ils ressortissent d'une décision du pouvoir central, ils pouvaient aussi servir au contrôle de la population locale, et même de centre de collecte des taxes. 


\section{AUTEURS}

RÉMY BOUCHARLAT

CNRS, Lyon 